\title{
The Role of Galectins in Chronic Lung Allograft Dysfunction
}

\author{
Miriana d'Alessandro ${ }^{1}$ (D) Laura Bergantini $^{1} \cdot$ Antonella Fossi $^{1} \cdot$ Elda De Vita ${ }^{1} \cdot$ Felice Perillo $^{1} \cdot$ Luca Luzzi $^{2}$. \\ Piero Paladini ${ }^{2} \cdot$ Piersante Sestini $^{1} \cdot$ Paola Rottoli $^{1}$ - Elena Bargagli ${ }^{1} \cdot$ David Bennett $^{1}$
}

Received: 15 December 2020 / Accepted: 16 April 2021 / Published online: 3 May 2021

(c) The Author(s) 2021

\begin{abstract}
Background Galectins are proteins that bind $\beta$-galactosides such as $\mathrm{N}$-acetyllactosamine present in $\mathrm{N}$-linked and O-linked glycoproteins and that seem to be implicated in inflammatory and immune responses as well as fibrotic mechanisms. This preliminary study investigated serum galectins as clinical biomarkers in lung transplant patients with chronic lung allograft dysfunction (CLAD), phenotype bronchiolitis obliterans syndrome (BOS).

Materials and Methods Nineteen lung transplant patients [median age (IQR), 55 (45-62) years; 53\% males] were enrolled in the study. Peripheral blood concentrations of galectins-1, 3 and 9 were determined with commercial ELISA kits.

Results Galectin-1 concentrations were higher in BOS than in stable LTX patients $(p=0.0394)$. In logistic regression analysis, testing BOS group as dependent variable with Gal-1 and 3 as independent variables, area under the receiver operating characteristics (AUROC) curve was 98.9\% (NPV 90\% and PPV 88.9\%, $p=0.0003$ ). With the stable LTX group as dependent variable and Gal-1, 3 and 9 as independent variables, AUROC was 92.6\% (NPV 100\% and PPV 90\%, $p=0.0023$ ). In stable patients were observed an inverse correlation of Gal-3 with DLCO \% and KCO\%, and between Gal-9 and KCO\%.

Conclusion Galectins-1, 3 and 9 are possible clinical biomarkers in lung transplant patients with diagnostic and prognostic meaning. These molecules may be directly implicated in the pathological mechanisms of BOS. The hypothesis that they could be new therapeutic targets in BOS patients is intriguing and also worth exploring.
\end{abstract}

Keywords Galectin-1 - Galectin-3 - Galectin-9 $\cdot$ Lung transplantation $\cdot$ Chronic lung allograft dysfunction $\cdot$ Biomarkers

\section{Introduction}

Lung transplant (LTX) is a lifesaving treatment option for patients with end-stage lung diseases, including emphysema, cystic fibrosis, pulmonary fibrosis and pulmonary arterial hypertension, unresponsive to maximal medical therapy or for whom no effective medical or other surgical alternative exists [1-4]. Long-term survival after LTX is still challenging and chronic lung allograft dysfunction (CLAD) remains a leading cause of death [5]. Bronchiolitis obliterans syndrome (BOS) is the most common form of CLAD

Miriana d'Alessandro

dalessandro.miriana@gmail.com

1 Respiratory Diseases Unit, Department of Medical Sciences, University Hospital of Siena (Azienda Ospedaliera Universitaria Senese, AOUS), Viale Bracci, 53100 Siena, Italy

2 Thoracic Surgery Unit, Cardio-Thoracic and Vascular Department, University Hospital of Siena (Azienda Ospedaliera Universitaria Senese, AOUS), Siena, Italy and appears to begin with an inflammatory stage, characterized by lymphocytic peribronchiolar infiltrates, and then progresses to a fibroproliferative stage with proliferation of fibroblasts and accumulation of collagen under the bronchiolar epithelium, leading to obliteration of the airway lumen [6]. A restrictive form of CLAD, termed restrictive allograft syndrome (RAS), has also recently been recognized [7].

Galectins (Gal) are proteins that bind $\beta$-galactosides, such as $\mathrm{N}$-acetyllactosamine, present in $\mathrm{N}$-linked and O-linked glycoproteins. Galectin structure features one or two carbohydrate recognition domains, on the basis of which they are classified as prototype galectins (e.g. Gal-1), chimera galectins (e.g. Gal-3) and tandem-repeat galectins (e.g. Gal9). Galectins have numerous biological functions: they participate in cross-talk and maintenance of cell architecture, facilitating interactions between cells and components of the extracellular matrix [8]. These cell-cell and cell-matrix interactions, as well as signalling pathways on the cell surface, influence and modulate cell functions, such as inflammatory and immune responses [9]. Depending on the type 
of inflammatory stimulus, the microenvironment and the target cells involved, these proteins may be associated with pro- or anti-inflammatory responses [10]. Galectins are also implicated in pulmonary fibrosis, where their inhibition may be useful in therapeutic management [11-14]. Some reports show that malignant transformation in human cancer patients is often associated with altered galectin expression [15]. Galectins play a crucial role in the homeostasis of inflammation through their apoptotic effect on activated leukocytes $[11,16]$. Release of Gals- 1 and 3 initiates an inflammatory response in several ways, including binding of neutrophils to the endothelium, trafficking of neutrophils through the extracellular matrix bound to laminins and fibronectin, and acting as chemotactic agents towards the site of inflammation $[12,13]$. Once neutrophils have been trafficked to the scene, galectins- 1 and 3 then contribute to the respiratory burst that enables neutrophils to destroy cell contents or invading pathogens $[8,17]$. Some data in kidney and liver transplantation have been published regarding their potential role in graft tolerance $[18,19]$, but no data is available on the role of galectins in LTX patients. In the present study our aim was to explore the potential of serum concentrations of galectins- 1,3 and 9 as clinical biomarkers in lung transplant patients with BOS.

\section{Materials and Methods}

\section{Study Population}

Nineteen lung transplant patients [median age (IQR), 55 (45-62) years; 53\% males] monitored at the Siena Regional Referral Centre for Sarcoidosis and other Interstitial Lung Diseases were enrolled in the study. Nine patients [median age (IQR), 51 (49-63) years; 33\% males] were considered stable (CLAD-free), whereas the other ten patients [median age (IQR), 58 (37-62) years; 70\% males] had CLAD (BOS phenotype). A healthy control group (HC) was also included ( $n=9$; median age (IQR), 45 (35-54) years; 33\% males).

CLAD was defined in presence of a substantial and persistent decline $(\geq 20 \%)$ in measured $\mathrm{FEV}_{1}$ value from the reference (baseline) value. The baseline value was computed as the mean of the best two postoperative $\mathrm{FEV}_{1}$ measurements (taken $>3$ weeks apart). BOS phenotype was assumed in case of a fall in $\mathrm{FEV}_{1} \geq 20 \%$ (compared with baseline) in presence of an obstruction pattern at spirometry $\left(\mathrm{FEV}_{1} /\right.$ FVC $<0.7$ ) without persistent radiologic pulmonary opacities (parenchymal opacities and/or increasing pleural thickening consistent with a diagnosis of pulmonary and/or pleural fibrosis and likely to cause a restrictive physiology, rather than the airway-based changes consistent with bronchiectasis) [6]. All included patients met BOS diagnostic criteria, patients with RAS were excluded.
All clinical and functional data was collected retrospectively and entered in a specific database. Patients gave their written informed consent to participation in the study, which was approved by our local ethics committee (Respir 1 , Prot $n$ 15,732, 16 September 2019).

\section{Lung Function Tests}

Lung function measurements were performed according to ATS/ERS standard procedure [20], using a Jaeger body plethysmograph with corrections for temperature and barometric pressure: forced expiratory volume in the first second (FEV1), forced vital capacity (FVC), total lung capacity (TLC), residual volume (RV), diffusing capacity of the lung for carbon monoxide (DLCO) and carbon monoxide transfer coefficient (KCO) for alveolar volume. All parameters were expressed as percentages of predicted values. They were recorded at sampling time and after LTX in order to establish CLAD stage.

\section{Galectin Assay}

Peripheral blood concentrations of galectins-1, 3 and 9 were determined with the Human Galectin quantikine ELISA kit (R\&D System, Minneapolis, USA). Nine serum samples were also collected from the healthy volunteers and assayed. The serum concentrations of Gal-1 [mean (IQR), 18.1 (13.9-28.2) ng/ml], Gal-3 [mean (IQR), 6.73 (2.40-15.7) $\mathrm{ng} / \mathrm{ml}$ ] and Gal-9 [mean (IQR), 7 (3.1-10.4) ng/ml] of controls were in line with those indicated by the kit manufacturer [21].

\section{Statistical Analysis}

The data did not show a normal distribution. The Mann-Whitney test was used for comparison of two variables, while non-parametric one-way ANOVA (Kruskal-Wallis test) and the Dunn test were used for multiple comparisons. The Chi-squared test was used for categorical variables, as appropriate. According to the presence of BOS phenotype, our population were divided in CLAD-free and CLAD-BOS group.

We also performed a logistic regression with $\mathrm{HC}$ as dependent variable against CLAD-BOS (or CLAD-free) to assess the potential of the serum galectins for differential diagnosis between the groups. Sensitivity, specificity, and positive and negative predicted values (PPV and NPV, respectively) were calculated for cut-offs of the different variables. Correlations between variables were studied by Spearman correlation and linear regression. A p-value less than 0.05 was considered statistically significant. Statistical analysis and graphic representation of the data was performed with GraphPad Prism 8.0 software. Unsupervised 
and supervised Principal Component Analysis (PCA) was performed by ClustVis (https://biit.cs.ut.ee/clustvis).

\section{Results}

The main characteristics of our population, including serum concentrations of galectins-1, 3 and 9 and lung function parameters, are reported in Table 1.

Galectin-1, 3 and 9 concentrations were significantly higher in CLAD-BOS patients than in HC $(p=0.0018$, $p=0.0122$ and $p=0.0003$, respectively). Galectin- 1 concentrations were higher in CLAD-BOS than in CLAD-free patients $(p=0.0394)$; Gal-9 concentrations were higher in the CLAD-free group than in the HC group $(p=0.0231)$ (Table 1, Fig. 1). No difference in Galectin-1, 3 and 9 concentrations accordingly underling lung disease or other basal characteristics were observed.

PCA analysis was performed with the results obtained for serum concentrations of galectins. The eigenvalue percentage significance of the PCs was $99.9 \%$. Intraclass dispersion

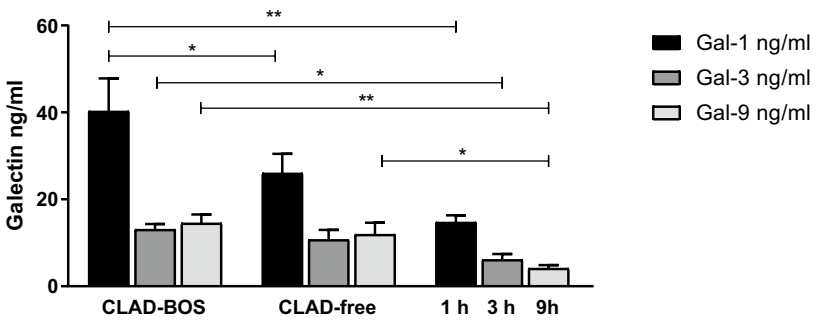

Fig. 1 Galectin concentrations in LTX patients, including CLAD and stable patients and healthy controls. ${ }^{*} p<0.05 ;{ }^{* *} p<0.005$

occurred mainly along the first and second PCs. The three groups separated along the first PC (Fig. 2).

Testing the HC group as dependent variable by logistic regression, with Gal-1, 3 and 9 as independent variables, we obtained an area under the ROC (AUROC) curve of $96.5 \%$ (95\% CI 89-100, NPV 100\% and PPV 90\%, $p<0.0001$ ) (Fig. 3a). When we tested the CLAD-BOS group as dependent variable with Gal-1 and 3 as independent variables, AUROC was 98.9\% (95\% CI 95-100, NPV 90\% and PPV

Table 1 Main characteristic of population including age, gender, smoking habit, underling lung diseases and comorbidities, galectins and lung function test parameters

\begin{tabular}{|c|c|c|c|c|}
\hline Parameters & CLAD-free $(n=9)$ & CLAD-BOS $(n=10)$ & Healthy controls $(n=9)$ & \\
\hline Age & $49(51-63)$ & $37(58-62)$ & $25(30-58)$ & \\
\hline Gender (male/female) & $3 / 6$ & $7 / 3$ & $2 / 7$ & \\
\hline Smoking habit (never/former) & $6 / 3$ & $4 / 6$ & $4 / 5$ & \\
\hline \multicolumn{5}{|l|}{ Diagnosis } \\
\hline Pulmonary fibrosis & $4(44.5 \%)$ & $3(30 \%)$ & & 0.51 \\
\hline COPD & $2(22.3 \%)$ & $3(30 \%)$ & & 0.70 \\
\hline Cystic fibrosis & $2(22.3 \%)$ & $4(40 \%)$ & & 0.40 \\
\hline Other diagnosis & - & - & & - \\
\hline \multicolumn{5}{|l|}{ Comorbidities } \\
\hline Diabetes mellitus & $2(22.3 \%)$ & $5(50 \%)$ & & 0.21 \\
\hline Arterial hypertension & $1(11.2 \%)$ & $3(30 \%)$ & & 0.31 \\
\hline Hypercholesterolemia & $2(22.3 \%)$ & $4(40 \%)$ & & 0.40 \\
\hline Osteoporosis & $4(44.5 \%)$ & $7(70 \%)$ & & 0.58 \\
\hline \multicolumn{5}{|l|}{ Galectins concentration } \\
\hline Gal-1 (mg/dl) & $22.7(18.7-29.4)$ & $29.9(25.6-58.1)$ & $13.1(11.6-16.6)$ & 0.0026 \\
\hline Gal-3 (mg/dl) & $10.7(4.6-17.6)$ & $12.1(9.4-16.9)$ & $6.2(3-8.1)$ & 0.0154 \\
\hline Gal-9 (mg/dl) & $8.6(7.3-15.6)$ & $12.3(9.3-19.3)$ & $3.8(2.1-6.1)$ & 0.0003 \\
\hline \multicolumn{5}{|l|}{ LFTs } \\
\hline $\mathrm{FVC}(\mathrm{ml})$ & $2460(2150-3445)$ & $2765(2273-2945)$ & & $>0.999$ \\
\hline $\mathrm{FVC} \%$ & $90(71-99)$ & $69(61-85)$ & & 0.0877 \\
\hline FEV1 (ml) & $2090(1710-2580)$ & $1800(1303-2138)$ & & 0.2359 \\
\hline FEV1 (\%) & $87(66-91)$ & $57(42-71)$ & & 0.0079 \\
\hline FEV1/VC & $81(73-87)$ & $64(62-70)$ & & 0.0293 \\
\hline $\operatorname{DLCO}(\%)$ & $69(55-78)$ & $62(54-85)$ & & 0.7243 \\
\hline $\mathrm{KCO}(\%)$ & $82(72-95)$ & $92(71-108)$ & & 0.6304 \\
\hline
\end{tabular}

All data were expressed as median and Interquartile range 


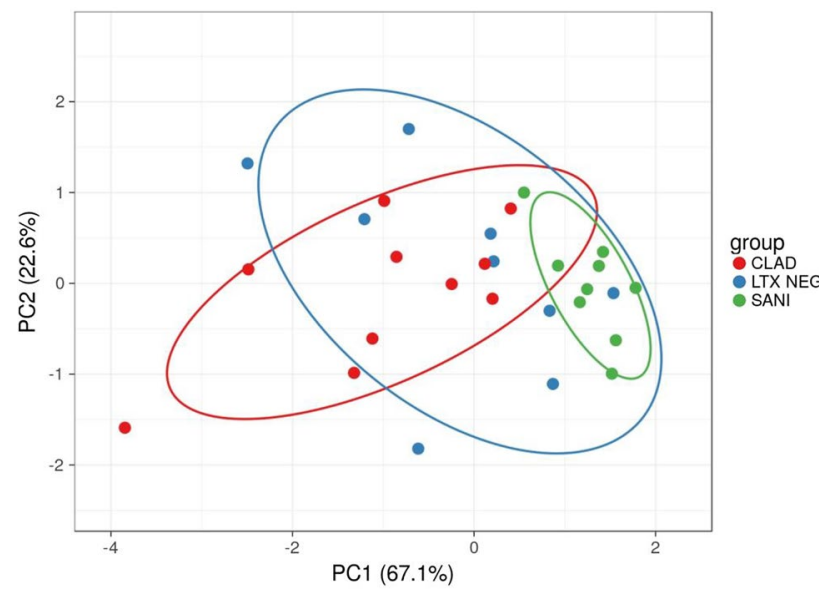

Fig. 2 Unit variance scaling is applied to rows; SVD with imputation is used to calculate principal components. $X$ and $Y$ axis show principal component 1 and principal component 2 that explain $67.1 \%$ and $22.6 \%$ of the total variance, respectively. Prediction ellipses are such that with probability 0.95 , a new observation from the same group will fall inside the ellipse. $N=28$ data points. LTX neg stable LTX; $C L A D$ chronic allograft lung dysfunction

$88.9 \%, p=0.0003$ ) (Fig. 3b). With the CLAD-free group as dependent variable and Gal-1, 3 and 9 as independent variables, AUROC was $92.6 \%$ (95\% CI 78-100, NPV 100\% and PPV 90\%, $p=0.0023$ ) (Fig. 3c).

A significant inverse correlation of Gal-3 with DLCO\% and $\mathrm{KCO} \%$ was observed among CLAD-free, while Gal-9 showed inverse correlations with $\mathrm{KCO} \%$ among stable patients, and with measured FVC in CLAD-BOS patients (the latter with borderline significance, but with a good Rho coefficient: $-0.714, p=0.058$ ) (Table 2). No significant correlations were observed between Gal-1 concentrations and lung function parameters (Table 2).

\section{Discussion}

BOS is the most frequent presenting phenotype of CLAD. It is characterized by bronchiole thickening and obstruction due to injury and inflammation of epithelial cells and small airway subepithelial structures, leading to fibroproliferation and aberrant tissue repair [22]. Since pathogenesis is very complex, there are currently no biomarkers for early diagnosis of BOS or with clear clinical prognostic significance. The present exploratory study evaluated serum concentrations of galectins-1, 3 and 9 for the first time in LTX recipients, with and without BOS, and in healthy controls to assess their potential role as clinical biomarkers.

Gal-1 has been demonstrated to play a negative prognostic role in several conditions, including cancer and fibrotic processes [23, 24]. In transplantation, Gal-1 has shown to participate to hepatic graft tolerance and has been postulated it can be implicated in the inhibition of dendritic cells-mediated allogeneic $\mathrm{T}$ cell stimulation and survival and Th1/ Th17 production $[19,25,26]$. It is also implicated in the dysregulation of the ERK/MAPK pathway [12] and plays its major function of immunomodulation determining the reduction of INF-gamma and inducing IL5 and IL10 production under inflammatory conditions [17] thus participating to neutrophil homeostasis [27]. While in a rat model of acute kidney rejection Gal-1 showed a potential protective role [28], more recently it was found increased in the glomeruli of kidney transplant patients with antibody-mediated rejection and proposed as potential therapeutic target to prevent extracellular matrix remodelling in such condition [29]. In the present study, higher serum concentrations of Gal-1 were observed in CLAD patients with BOS than in CLADfree patients and healthy controls, which could be related to the inflammatory status of patients in the chronic rejection group. BAL neutrophilia is a common finding in BOS patients that can predict response to azithromycin therapy [30, 31]. Galectin-1 can positively or negatively modulate the effector functions of neutrophils according to cell activation stage [32] and its increased concentration might reflect the activation of neutrophils in BOS. Some earlier studies reported anti-inflammatory action of Gal-1, initially by modulation of pro-inflammatory cytokine release and PMN migration through an imbalance of adhesion molecule expression, and later by promoting monocyte-macrophage recruitment [33]. Galectin-1 can also activate neutrophils through CD43, depending on the environment in which it acts [34]. Our results highlight the potential of Gal-1 as a clinical biomarker of BOS and suggest that it plays an as yet undefined part in the pathogenic mechanisms of BOS.

In the present study, higher serum concentrations of Gal-3 were observed in CLAD patients with BOS than in healthy controls, although its levels in BOS patients did not differ significantly with respect to those of CLAD-free patients. Galectin-3 concentrations were correlated with DLCO\% and $\mathrm{KCO} \%$ in CLAD-free patients. Elevated Gal-3 concentrations are known to be correlated with various inflammatory and fibrotic conditions, including idiopathic pulmonary fibrosis, cardiovascular disease, autoimmune diseases, cancer and osteoarthritis, but no data is yet available on lung transplant patients $[35,36]$. Galectin-3 seems to play a role in renal Ischemic-reperfusion injury involving the secretion of macrophage-related chemokine, pro-inflammatory cytokines and ROS production [37].

Our limited number of patients does not allow us a safe interpretation of this result; however, the possible association with some pre-CLAD lung pathological process within the graft is interesting and need further exploration.

Galectin-9 was first identified as a chemoattractant and activation factor of eosinophils in vitro and in vivo [38]. It modulates different biological functions including cell 


\section{Gal-1,3,9 HC vs LTX}

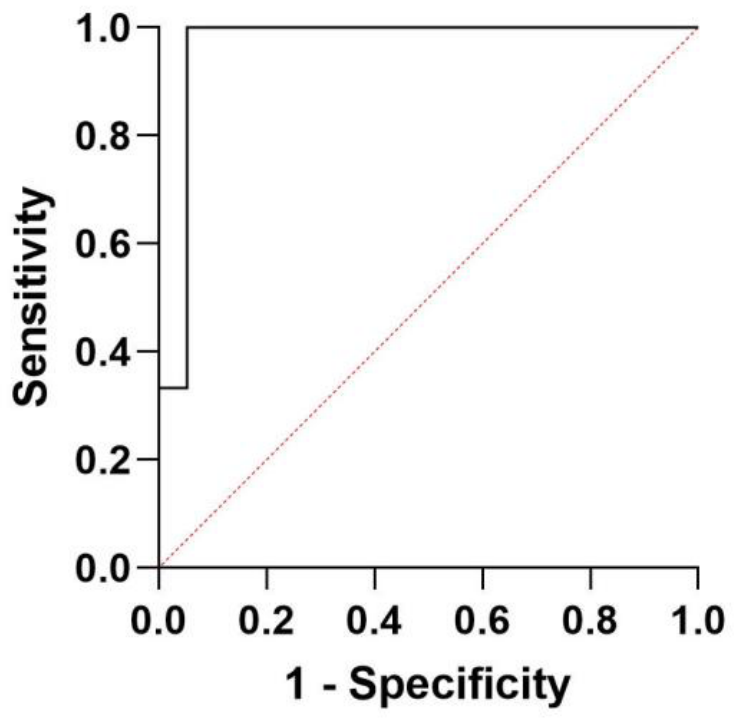

$\mathbf{a}$

\section{Gal-1,3,9 HC vs CLAD-free}

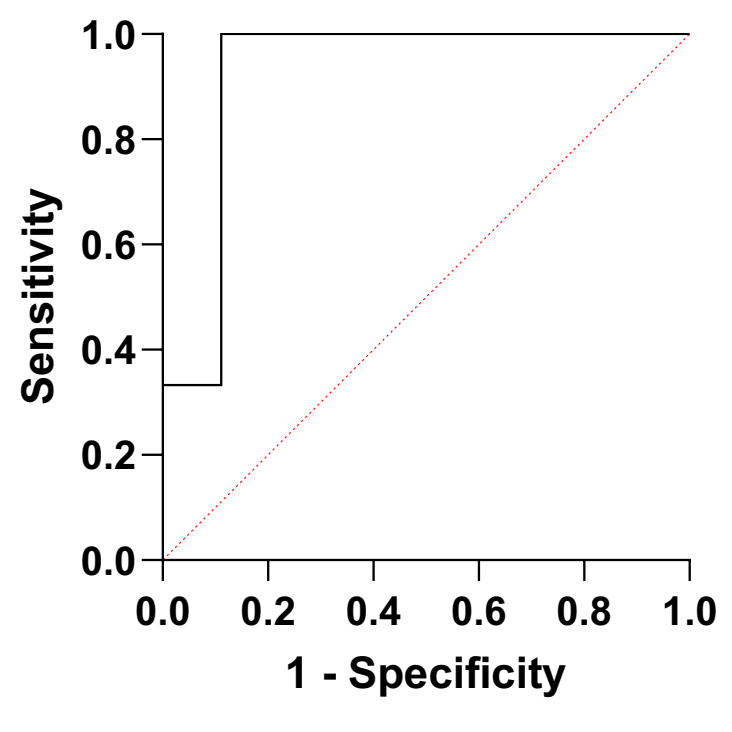

Fig. 3 a HC group as dependent variable and Gal-1,3,9 as independent variables, areas under the ROC (AUROC) curve of 96.5\% $(95 \%$ CI 89-100, NPV 100\% and PPV 90\%, $p<0.0001)$. b CLAD group as dependent variable with Gal-1 and 3 as independent variables,

aggregation and adhesion, as well as apoptosis of tumour cells. Few papers reported the prognostic role of Gal-9 in different organ transplantations in which Gal-9 expression after allo-hematopoietic stem cell and liver transplantation

\section{Gal-1,3 HC vs CLAD-BOS}

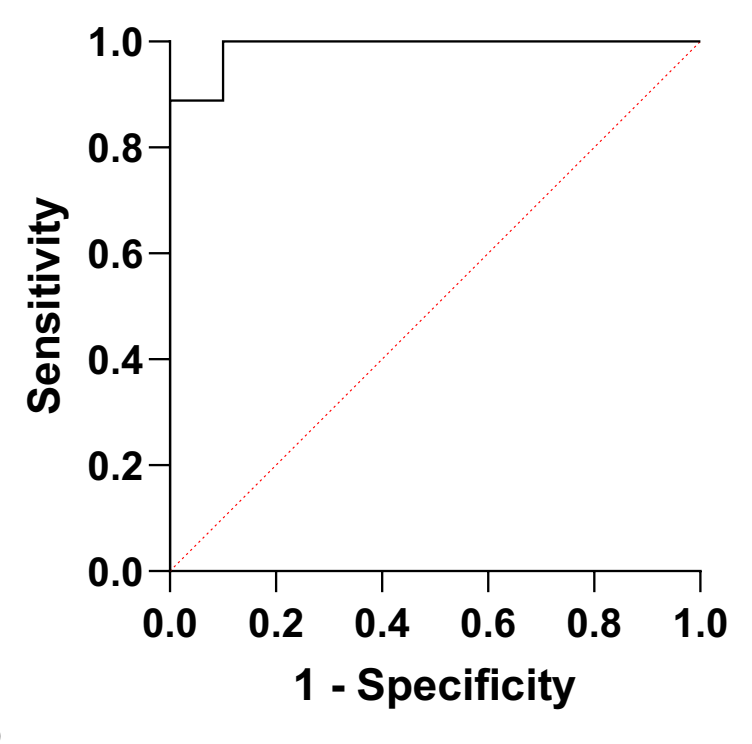

b 
Table 2 Main correlations between Galectin concentrations and LFT parameters

\begin{tabular}{|c|c|c|c|c|c|c|c|}
\hline \multicolumn{2}{|c|}{ CLAD-free } & \multirow{2}{*}{$\begin{array}{c}\text { Rho coefficient } \\
0.217\end{array}$} & \multirow{2}{*}{$\frac{P \text { value }}{0.581}$} & \multicolumn{2}{|c|}{ CLAD-BOS } & \multirow{2}{*}{$\begin{array}{l}\text { Rho coefficient } \\
-0.275\end{array}$} & \multirow{2}{*}{$\frac{P \text { value }}{0.507}$} \\
\hline Gal-1 & $\mathrm{FVC} \%$ & & & Gal-1 & $\mathrm{FVC} \%$ & & \\
\hline & $\mathrm{FVC}(\mathrm{ml})$ & 0.400 & 0.291 & & $\mathrm{FVC}(\mathrm{ml})$ & -0.190 & 0.665 \\
\hline & FEV1\% & 0.517 & 0.162 & & FEV1\% & -0.238 & 0.582 \\
\hline & FEV1(ml) & 0.550 & 0.133 & & $\mathrm{FEV}(\mathrm{ml})$ & 0.095 & 0.840 \\
\hline & DLCO $\%$ & -0.117 & 0.776 & & DLCO $\%$ & 0.300 & 0.683 \\
\hline & $\mathrm{KCO} \%$ & -0.367 & 0.336 & & $\mathrm{KCO} \%$ & 0.600 & 0.350 \\
\hline & RV\% & 0.453 & 0.882 & & $\mathrm{RV} \%$ & 0.369 & 0.332 \\
\hline & TLC $\%$ & 0.190 & 0.772 & & TLC $\%$ & 0.309 & 0.730 \\
\hline \multirow[t]{8}{*}{ Gal-3 } & $\mathrm{FVC} \%$ & -0.117 & 0.776 & Gal-3 & $\mathrm{FVC} \%$ & 0.323 & 0.434 \\
\hline & $\mathrm{FVC}(\mathrm{ml})$ & -0.083 & 0.843 & & $\mathrm{FVC}(\mathrm{ml})$ & 0.262 & 0.536 \\
\hline & FEV1\% & -0.450 & 0.230 & & FEV1\% & 0.571 & 0.151 \\
\hline & FEV1(ml) & -0.333 & 0.385 & & FEV1(ml) & 0.619 & 0.115 \\
\hline & DLCO $\%$ & -0.800 & 0.014 & & DLCO $\%$ & 0.300 & 0.683 \\
\hline & $\mathrm{KCO} \%$ & -0.683 & 0.050 & & $\mathrm{KCO} \%$ & 0.100 & 0.950 \\
\hline & $\mathrm{RV} \%$ & 0.112 & 0.213 & & RV\% & 0.192 & 0.782 \\
\hline & TLC $\%$ & 0.310 & 0.221 & & TLC\% & 0.886 & 0.033 \\
\hline \multirow[t]{8}{*}{ Gal-9 } & $\mathrm{FVC} \%$ & 0.133 & 0.744 & Gal-9 & $\mathrm{FVC} \%$ & -0.623 & 0.105 \\
\hline & $\mathrm{FVC}(\mathrm{ml})$ & 0.033 & 0.948 & & $\mathrm{FVC}(\mathrm{ml})$ & -0.714 & 0.058 \\
\hline & FEV1\% & -0.183 & 0.644 & & FEV1\% & -0.643 & 0.096 \\
\hline & FEV1(ml) & -0.167 & 0.678 & & FEV1(ml) & -0.595 & 0.132 \\
\hline & DLCO $\%$ & -0.567 & 0.121 & & DLCO $\%$ & -0.100 & 0.950 \\
\hline & $\mathrm{KCO} \%$ & -0.800 & 0.014 & & $\mathrm{KCO} \%$ & -0.200 & 0.783 \\
\hline & RV\% & 0.683 & 0.05 & & RV\% & 0.143 & 0.867 \\
\hline & TLC $\%$ & 0.700 & 0.043 & & TLC\% & 0.324 & 0.584 \\
\hline
\end{tabular}

its immunoregulatory role during the ongoing cytotoxic response [43]. In the present study, we recorded higher serum concentrations of Gal-9 in LTX patients than in healthy controls. Our findings can be traced back to fibroproliferation and aberrant tissue repair after injury and inflammation of small airway subepithelial structures in BOS patients. We also found inverse correlations between Gal-9 and $\mathrm{KCO} \%$ in CLAD-free patients and between Gal-9 and measured FVC in CLAD-BOS, suggesting that this protein could be a negative prognostic marker in LTX recipients.

The limits of the present study were its monocentric and retrospective nature and small statistical sample. However, as an exploratory study into the role of galectins in lung transplant patients, it could pave the way for new research into their clinical and pathogenic participation in BOS. No specific hypothesis on their mechanistic role in lung transplantation can be made at this point; however, our study shines a first spotlight on galectins in chronic lung allograft dysfunction suggesting their potentiality as marker for homeostatic mechanisms of the graft that worth to investigate.

In conclusion, this is the first study to evaluate galectins concentrations in serum of LTX recipients. Our results reveal overexpression of these molecules in CLAD patients with BOS phenotype correlated with several respiratory function parameters. Galectins-1, 3 and 9 are possible clinical diagnostic and prognostic biomarkers, worthy of further study in larger populations in order to clarify their role in lung transplant. These molecules may be directly implicated in the pathological mechanisms of BOS. The hypothesis that they could be new therapeutic targets in BOS patients is intriguing and also worth exploring.

Acknowledgments We are very grateful to the support of the "ASSOCIAZIONE PROFONDI RESPIRI ONLUS".

Funding Open access funding provided by Università degli Studi di Siena within the CRUI-CARE Agreement. The present study was founded by Organizzazione Toscana Trapianti (OTT) (Grant 2019 DGRT 641).

\section{Declarations}

Conflict of interest The authors declare that they have no conflict of interest to disclose.

Ethical Approval The research was approved by the local ethics committee (Respir1, Prot n 15732, 16 September 2019).

Consent to Participate All subjects gave their written informed consent to the study. 
Open Access This article is licensed under a Creative Commons Attribution 4.0 International License, which permits use, sharing, adaptation, distribution and reproduction in any medium or format, as long as you give appropriate credit to the original author(s) and the source, provide a link to the Creative Commons licence, and indicate if changes were made. The images or other third party material in this article are included in the article's Creative Commons licence, unless indicated otherwise in a credit line to the material. If material is not included in the article's Creative Commons licence and your intended use is not permitted by statutory regulation or exceeds the permitted use, you will need to obtain permission directly from the copyright holder. To view a copy of this licence, visit http://creativecommons.org/licenses/by/4.0/.

\section{References}

1. Bennett D, Lanzarone N, Fossi A, Perillo F, De Vita E, Luzzi L, Paladini P, Bargagli E, Sestini P, Rottoli P (2020) Pirfenidone in chronic lung allograft dysfunction: a single cohort study. Panminerva Med 62(3):143-149. https://doi.org/10.23736/S0031-0808. 19.03840-0

2. Bennett D, De Vita E, Fossi A, Bargagli E, Paladini P, Luzzi L, Franchi F, Scolletta S, Sestini P (2020) Outcome of ECMO bridge to lung transplantation: a single cohort study. Minerva Med. https://doi.org/10.23736/S0026-4806.20.06744-0

3. Cameli P, Bargagli E, Fossi A, Bennett D, Voltolini L, Refini RM, Gotti G, Rottoli P (2015) Exhaled nitric oxide and carbon monoxide in lung transplanted patients. Respir Med 109(9):1224-1229. https://doi.org/10.1016/j.rmed.2015.07.005

4. Bennett D, Fossi A, Bargagli E, Refini RM, Pieroni M, Luzzi L, Ghiribelli C, Paladini P, Voltolini L, Rottoli P (2015) Mortality on the waiting list for lung transplantation in patients with idiopathic pulmonary fibrosis: a single-centre experience. Lung 193(5):677-681. https://doi.org/10.1007/s00408-015-9767-x

5. Bergantini L, d'Alessandro M, De Vita E, Perillo F, Fossi A, Luzzi L, Paladini P, Perrone A, Rottoli P, Sestini P, Bargagli B, Bennett D (2021) Regulatory and effector cell disequilibrium in patients with acute cellular rejection and chronic lung allograft dysfunction after lung transplantation: comparison of peripheral and alveolar distribution. Cells 10(4):780

6. Verleden GM, Glanville AR, Lease ED, Fisher AJ, Calabrese F, Corris PA, Ensor CR, Gottlieb J, Hachem RR, Lama V, Martinu T, Neil DAH, Singer LG, Snell G, Vos R (2019) Chronic lung allograft dysfunction: definition, diagnostic criteria, and approaches to treatment-a consensus report from the Pulmonary Council of the ISHLT. J Heart Lung Transplant 38(5):493-503. https://doi. org/10.1016/j.healun.2019.03.009

7. Ofek E, Sato M, Saito T, Wagnetz U, Roberts HC, Chaparro C, Waddell TK, Singer LG, Hutcheon MA, Keshavjee S, Hwang DM (2013) Restrictive allograft syndrome post lung transplantation is characterized by pleuroparenchymal fibroelastosis. Mod Pathol 26(3):350-356. https://doi.org/10.1038/modpathol.2012.171

8. Liu FT, Patterson RJ, Wang JL (2002) Intracellular functions of galectins. Biochim Biophys Acta 1572(2-3):263-273. https://doi. org/10.1016/s0304-4165(02)00313-6

9. Rabinovich GA, Liu FT, Hirashima M, Anderson A (2007) An emerging role for galectins in tuning the immune response: lessons from experimental models of inflammatory disease, autoimmunity and cancer. Scand J Immunol 66(2-3):143-158. https:// doi.org/10.1111/j.1365-3083.2007.01986.x

10. Sundblad V, Morosi LG, Geffner JR, Rabinovich GA (2017) Galectin-1: a jack-of-all-trades in the resolution of acute and chronic inflammation. J Immunol 199(11):3721-3730. https:// doi.org/10.4049/jimmunol.1701172
11. d'Alessandro M, De Vita E, Bergantini L, Mazzei MA, di Valvasone S, Bonizzoli M, Peris A, Sestini P, Bargagli E, Bennett D (2020) Galactin-1, 3 and 9: potential biomarkers in idiopathic pulmonary fibrosis and other interstitial lung diseases. Respir Physiol Neurobiol 282:103546. https://doi.org/10.1016/j.resp. 2020.103546

12. Kathiriya JJ, Nakra N, Nixon J, Patel PS, Vaghasiya V, Alhassani A, Tian Z, Allen-Gipson D, Davé V (2017) Galectin-1 inhibition attenuates profibrotic signaling in hypoxia-induced pulmonary fibrosis. Cell Death Discov 3:17010. https://doi.org/10.1038/cddis covery.2017.10

13. Nishi Y, Sano H, Kawashima T, Okada T, Kuroda T, Kikkawa K, Kawashima S, Tanabe M, Goto T, Matsuzawa Y, Matsumura R, Tomioka H, Liu FT, Shirai K (2007) Role of galectin-3 in human pulmonary fibrosis. Allergol Int 56(1):57-65. https://doi.org/10. 2332/allergolint.O-06-449

14. Matsumoto N, Katoh S, Yanagi S, Arimura Y, Tokojima M, Ueno M, Hirashima M, Nakazato M (2013) A possible role of galectin-9 in the pulmonary fibrosis of patients with interstitial pneumonia. Lung 191(2):191-198. https://doi.org/10.1007/ s00408-012-9446-0

15. Thijssen VL, Heusschen R, Caers J, Griffioen AW (2015) Galectin expression in cancer diagnosis and prognosis: a systematic review. Biochim Biophys Acta 1855(2):235-247. https://doi.org/ 10.1016/j.bbcan.2015.03.003

16. Bennett D, Bargagli E, Bianchi N, Landi C, Fossi A, Fui A, Sestini P, Refini RM, Rottoli P (2020) Elevated level of Galectin-1 in bronchoalveolar lavage of patients with idiopathic pulmonary fibrosis. Respir Physiol Neurobiol 273:103323. https://doi.org/10. 1016/j.resp.2019.103323

17. Lei T, Moos S, Klug J, Aslani F, Bhushan S, Wahle E, Fröhlich S, Meinhardt A, Fijak M (2018) Galectin-1 enhances TNF $\alpha$-induced inflammatory responses in Sertoli cells through activation of MAPK signalling. Sci Rep 8(1):3741. https://doi.org/10.1038/ s41598-018-22135-w

18. Tan R, Liu X, Wang J, Lu P, Han Z, Tao J, Yin C, Gu M (2014) Alternations of galectin levels after renal transplantation. Clin Biochem 47(15):83-88. https://doi.org/10.1016/j.clinbiochem. 2014.06.019

19. García MJ, Jurado F, San Segundo D, López-Hoyos M, Iruzubieta P, Llerena S, Casafont F, Arias M, Puente Á, Crespo J, Fábrega E (2015) Galectin-1 in stable liver transplant recipients. Transplant Proc 47(1):93-96. https://doi.org/10.1016/j.transproceed.2014.12. 001

20. Culver BH, Graham BL, Coates AL, Wanger J, Berry CE, Clarke PK, Hallstrand TS, Hankinson JL, Kaminsky DA, MacIntyre NR, McCormack MC, Rosenfeld M, Stanojevic S, Weiner DJ (2017) ATS Committee on Proficiency Standards for Pulmonary Function Laboratories. Recommendations for a standardized pulmonary function report: an official American Thoracic Society Technical Statement. Am J RespirCrit Care Med 196(11):1463-1472. https://doi.org/10.1164/rccm.201710-1981ST

21. Human Galectin-1 ELISA Kit (ab260053) I Abcam 2020. https:// www.abcam.com/human-galectin-1-elisa-kit-ab260053.html

22. DerHovanessian A, Wallace WD, Lynch JP 3rd, Belperio JA, Weigt SS (2018) Chronic lung allograft dysfunction: evolving concepts and therapies. SeminRespirCrit Care Med 39(2):155171. https://doi.org/10.1055/s-0037-1618567

23. Mundt F, Johansson HJ, Forshed J, Arslan S, Metintas M, Dobra K, Lehtiö J, Hjerpe A (2014) Proteome screening of pleural effusions identifies galectin 1 as a diagnostic biomarker and highlights several prognostic biomarkers for malignant mesothelioma. Mol Cell Proteomics 13(3):701-715. https://doi.org/10.1074/mcp. M113.030775 
24. Zhou X, Li D, Wang X, Zhang B, Zhu H, Zhao J (2015) Galectin-1 is overexpressed in CD133+ human lung adenocarcinoma cells and promotes their growth and invasiveness. Oncotarget 6(5):3111-3122. https://doi.org/10.18632/oncotarget.3076

25. Jiang ZJ, Shen QH, Chen HY, Yang Z, Shuai MQ, Zheng S (2018) Galectin-1 restores immune tolerance to liver transplantation through activation of hepatic stellate cells. Cell PhysiolBiochem 48(3):863-879. https://doi.org/10.1159/000491955

26. Morelli AE, Thomson AW (2013) Galectin-1, immune regulation and liver allograft survival. Am J Transplant 13(3):535-536. https://doi.org/10.1111/ajt.12092

27. Sundqvist M, Welin A, Elmwall J, Osla V, Nilsson UJ, Leffler H, Bylund J, Karlsson A (2018) Galectin-3 type-C self-association on neutrophil surfaces; the carbohydrate recognition domain regulates cell function. J Leukoc Biol 103(2):341-353. https://doi.org/ 10.1002/JLB.3A0317-110R

28. Xu G, Tu W, Xu C (2010) Immunological tolerance induced by galectin-1 in rat allogeneic renal transplantation. Int Immunopharmacol 10(6):643-647. https://doi.org/10.1016/j.intimp.2010. 03.001

29. Clotet-Freixas S, McEvoy CM, Batruch I, Pastrello C, Kotlyar M, Van JAD, Arambewela M, Boshart A, Farkona S, Niu Y, Li Y, Famure O, Bozovic A, Kulasingam V, Chen P, Kim SJ, Chan E, Moshkelgosha S, Rahman SA, Das J, Martinu T, Juvet S, Jurisica I, Chruscinski A, John R, Konvalinka A (2020) Extracellular matrix injury of kidney allografts in antibody-mediated rejection: a proteomics study. J Am SocNephrol 31(11):2705-2724. https:// doi.org/10.1681/ASN.2020030286

30. Berastegui C, Gómez-Ollés S, Sánchez-Vidaurre S, Culebras M, Monforte V, López-Meseguer M, Bravo C, Ramon MA, Romero L, Sole J, Cruz MJ, Román A (2017) BALF cytokines in different phenotypes of chronic lung allograft dysfunction in lung transplant patients. Clin Transplant. https://doi.org/10.1111/ctr.12898

31. Gan CT, Ward C, Meachery G, Lordan JL, Fisher AJ, Corris PA (2019) Long-term effect of azithromycin in bronchiolitis obliterans syndrome. BMJ Open Respir Res 6(1):e000465. https://doi. org/10.1136/bmjresp-2019-000465

32. Rodrigues LC, Kabeya LM, Azzolini AECS, Cerri DG, Stowell SR, Cummings RD, Lucisano-Valim YM, Dias-Baruffi M (2019) Galectin-1 modulation of neutrophil reactive oxygen species production depends on the cell activation state. Mol Immunol 116:80-89. https://doi.org/10.1016/j.molimm.2019.10.001.Errat um.In:MolImmunol.2020Mar;119:59-63

33. Gil CD, Gullo CE, Oliani SM (2010) Effect of exogenous galectin-1 on leukocyte migration: modulation of cytokine levels and adhesion molecules. Int J Clin Exp Pathol 4(1):74-84

34. Auvynet C, Moreno S, Melchy E, Coronado-Martínez I, Montiel JL, Aguilar-Delfin I, Rosenstein Y (2013) Galectin-1 promotes human neutrophil migration. Glycobiology 23(1):32-42. https:// doi.org/10.1093/glycob/cws128
35. Lala RI, Puschita M, Darabantiu D, Pilat L (2015) Galectin-3 in heart failure pathology_-"another brick in the wall"? Acta Cardiol 70(3):323-331. https://doi.org/10.1080/ac.70.3.3080637

36. Reboul P, Martel-Pelletier J, Pelletier JP (2004) Galectin-3 in osteoarthritis: when the fountain of youth doesn't deliver its promises. Curr Opin Rheumatol 16(5):595-598. https://doi.org/10.1097/01. bor.0000129663.76107.d6

37. FernandesBertocchi AP, Campanhole G, Wang PH, Gonçalves GM, Damião MJ, Cenedeze MA, Beraldo FC, de Paula Antunes Teixeira V, Dos Reis MA, Mazzali M, Pacheco-Silva A, Câmara NO (2008) A role for galectin-3 in renal tissue damage triggered by ischemia and reperfusion injury. Transplant Int 21(10):9991007. https://doi.org/10.1111/j.1432-2277.2008.00705.x

38. Katoh S, Nobumoto A, Matsumoto N, Matsumoto K, Ehara N, Niki T, Inada H, Nishi N, Yamauchi A, Fukushima K, Hirashima M (2010) Involvement of galectin-9 in lung eosinophilia in patients with eosinophilic pneumonia. Int Arch Allergy Immunol 153(3):294-302. https://doi.org/10.1159/000314371

39. Yin J, Li L, Wang C, Zhang Y (2020) Increased Galectin-9 expression, a prognostic biomarker of aGVHD, regulates the immune response through the Galectin-9 induced MDSC pathway after allogeneic hematopoietic stem cell transplantation. Int Immunopharmacol 88:106929. https://doi.org/10.1016/j.intimp.2020. 106929

40. Zhang AB, Peng YF, Jia JJ, Nie Y, Zhang SY, Xie HY, Zhou L, Zheng SS (2019) Exosome-derived galectin-9 may be a novel predictor of rejection and prognosis after liver transplantation. J Zhejiang Univ Sci B 20(7):605-612. https://doi.org/10.1631/jzus. B1900051.Erratum.In:JZhejiangUnivSciB.2020Feb.;21(2):178

41. Zhou Q, Munger ME, Veenstra RG, Weigel BJ, Hirashima M, Munn DH, Murphy WJ, Azuma M, Anderson AC, Kuchroo VK, Blazar BR (2011) Coexpression of Tim-3 and PD-1 identifies a CD8+ T-cell exhaustion phenotype in mice with disseminated acute myelogenous leukemia. Blood 117(17):4501-4510. https:// doi.org/10.1182/blood-2010-10-310425

42. Li YM, Li Y, Yan L, Tang JT, Wu XJ, Bai YJ, An YF, Dai B, Yang CL, Wang LL, Shi YY (2019) Assessment of serum Tim-3 and Gal-9 levels in predicting the risk of infection after kidney transplantation. Int Immunopharmacol 75:105803. https://doi.org/ 10.1016/j.intimp.2019.105803

43. Naka EL, Ponciano VC, Cenedeze MA, Pacheco-Silva A, Câmara NO (2009) Detection of the Tim-3 ligand, galectin-9, inside the allograft during a rejection episode. Int Immunopharmacol 9(6):658-662. https://doi.org/10.1016/j.intimp.2008.11.013

Publisher's Note Springer Nature remains neutral with regard to jurisdictional claims in published maps and institutional affiliations. 